\title{
EFFECT OF PRE-TREATED AND TREATED VITAMIN D ON INSULIN RESISTANCE, LIPID PROFILE AND PLATELET INDICES IN ADULT DIABETIC MALE ALBINO RATS
}

\author{
By
}

\author{
Mohammad Abul-hasan Zoair \\ Medical Physiology Department, Faculty of Medicine, Al-Azhar University, Cairo \\ E-mail: drmohammads74@azhar.edu.eg
}

\begin{abstract}
Background: Diabetes mellitus (DM) is a chronic disease, and is one of the major and growing health problems due to its high prevalence, chronic nature and high risk of chronic complications. Low serum vitamin D correlates with insulin resistance, obesity, glucose intolerance and frank type II diabetes mellitus.

Objective: Investigate and evaluate the effect of pre-treated and treated vitamin D on insulin resistance, lipid profile and platelet indices in diabetic male albino rats.

Materials and methods: Forty adult male albino rats of a local strain were used and divided into four equal groups: Group I: Control received saline intraperitoneal in a dose of $1 \mathrm{~mL} / \mathrm{rat}$, Group II: Diabetic by a single intraperitoneal injection of alloxan (150 mg/kg body weight), Group III: Diabetic received vitamin D in a dose of $100 \mathrm{ng} / \mathrm{Kg}$ daily by gastric gavag for 10 weeks before induction of diabetes, and Group IV: Diabetic received vitamin $\mathrm{D}$ in a dose of $100 \mathrm{ng} / \mathrm{Kg}$ daily by gastric gavag for 10 weeks after induction of diabetes.

Results: A significant marked recovery in insulin and glucose levels was recorded in diabetic animals pretreated and treated with vitamin D. Also, homeostatic model assessment for insulin resistance (HOMAIR) returned to approximate normal value. The lipid profile in pretreated and treated diabetic rats with vitamin D improved as shown by the significant reduction in the values of TG, TC, LDL, and VLDL and low risk I and II associated with marked elevation of HDL. A significant decrease in the platelet count and its mean volume was recorded in pretreated and treated diabetic animals with vitamin D.
\end{abstract}

Conclusion: Vitamin D can be effective in inhibition and decreasing of insulin resistance, dyslipidemia and coagulation activity, and consequently the improvement of diabetes and its complications.

Key words: vitamin D, Diabetes, Lipid Profile, insulin resistance, platelets.

\section{INTRODUCTION}

Diabetes mellitus is a chronic disease, and it is one of the major health problems due to its high prevalence, chronic nature, and high risk of chronic complications. It is commonly associated with dyslipidemia and coagulation disorders, which are most major risk factors of coronary heart disease (CHD) in diabetic patients (Kelishadi et al., 2014).
Many retrospective, case-control, and prospective studies demonstrate a higher incidence and prevalence of type I diabetes mellitus with depressed vitamin D status. Similarly, low serum vitamin D correlates with insulin resistance, obesity, glucose intolerance and frank type II diabetes mellitus (Pajor and Sliwinska, 2019). 
Biologic effects of vitamin $\mathrm{D}$ result largely from its binding to the nuclear steroid hormone vitamin $\mathrm{D}$ receptor (VDR), which is found in virtually all tissues and is also closely related to the thyroid, retinoid, and peroxisome proliferator-activator receptors. Although all vitamin $\mathrm{D}$ metabolites bind the VDR, most biological effects are likely mediated by calcitriol because of its greater receptor affinity (Wang et al., 2017).

The present study was designed to evaluate the effect of pre-treated and treated vitamin $\mathrm{D}$ on insulin resistance, lipid profile and platelet indices in adult diabetic male albino rats.

\section{MATERIAL AND METHODS}

Forty adult male albino rats of a local strain weighing approximately 110-130 g, were purchased from Animal House Centre, Al-Azhar University, Cairo, Egypt, were housed in clear plastic cages $(40 \mathrm{x} 35 \mathrm{x} 30 \mathrm{~cm}$, 5 animals /cage) with wood chips as bedding and given a standard pellet rodent diet, in addition to water ad libitum. The rats were maintained under standard laboratory conditions at $25 \pm 20 \mathrm{C}$ and normal light/dark cycle, and kept for ten days before experiment for adaptation.

Induction of diabetes: The animals were rendered diabetes by a single intraperitoneal injection of alloxan (150 $\mathrm{mg} / \mathrm{kg}$ body weight) in a freshly prepared physiological saline. Diabetic state of animals was monitored for its stability for seven successive days after alloxan treatment. On day eight of alloxan injection, only animals with fasting blood glucose levels $>200 \mathrm{mg} / \mathrm{dl}$ were selected as diabetic rats for the current experiment (Szkudelski, 2001).

\section{Material Preparation:}

Vitamin D $\quad(1, \quad 25-$ dihydroxyvitamin D3) was obtained from a local pharmacy and dissolved in a vehicle consisting of water/propylene glycol/ethanol 50/40/10. The dose of 1,25dihydroxyvitamin D3 of 100 $\mathrm{ng} / \mathrm{kg} /$ day was given orally for 10 weeks (Maren et al., 2017).

Experimental Design: Forty adult male albino rats of a local strain were used and divided into four equal groups:

Group I: Control received saline i.p. in a dose of $1 \mathrm{~mL} / \mathrm{rat}$.

Group II: Diabetic by a single intraperitoneal injection of alloxan (150 mg/kg body weight).

Group III: Diabetic received vitamin $\mathrm{D}$ in a dose of $100 \mathrm{ng} / \mathrm{Kg}$ daily by gastric gavag for 10 weeks before induction of diabetes.

Group IV: Ddiabetic received vitamin $\mathrm{D}$ in a dose of $100 \mathrm{ng} / \mathrm{Kg}$ daily by gastric gavag for 10 weeks after induction of diabetes.

Collection of blood and estimation of biochemical parameters: At the end of the experiment, blood samples were collected after overnight fasting rats in centrifuge tubes by retroorbital puncture under mild ether anesthesia. Blood samples were used in separation of sera by centrifugation at $4000 \mathrm{rpm}$ for $10 \mathrm{~min}$ at $4^{\circ} \mathrm{C}$, and immediately stored at $-80^{\circ} \mathrm{C}$ for 
further analysis of biochemical parameters.

Some whole blood samples were immediately used for platelet count and mean platelet volume using an automated blood cell counter (ADVIA 2120I, Bayer, NY, USA).

Serum total cholesterol (Henry et al., 1997), triglycerides (Fossati and Principe, 1982) and HDL (Burstein and Scholnick, 1972) were estimated colorimetrically, while LDL, VLDL, risk1and 2 were calculated by applying the Friedwald's equation (Friedewald et al., 1972):

Friedewald's equation: LDL (mg/dl) $=\mathrm{TC}-[\mathrm{HDL}+\mathrm{TG} / 5] . \mathrm{VLDL}=\mathrm{TG} / 5$

Risk ratio $1=\mathrm{TC} / \mathrm{HDL}$ Risk ratio 2 $=\mathrm{LDL} / \mathrm{HDL}$

Serum glucose was estimated according to the method of Trinder (1969). Serum insulin level was measured by an enzyme immunoassay kit (SPI-Bio société de pharmacologieet d'lmmunoloie-Bio, France), while values of homeostatic model assessment for insulin resistance (HOMA-IR) were calculated using the equation: HOMA-IR = fasting serum glucose $(\mathrm{mg} / \mathrm{dl}) \quad \mathrm{x}$ fasting serum insulin $(\mu \mathrm{U} / \mathrm{ml}) / 405$.

Statistical Analysis: The results were expressed as mean $\pm \mathrm{SE}$, and the statistical significance was evaluated by one way analysis of variance (ANOVA) and Kruskal-Wallis test followed by Duncan post Hoc test using Statistical Program of Social Sciences (SPSS) for windows (version 17, SPSS Inc., Chicago, IL, USA) software. Values were considered statistically significant at $\mathrm{P}$ $\leq 0.05$.

\section{RESULTS}

A significant decrease in the levels of serum fasting insulin accompanied with marked significant elevation in the level of fasting blood glucose were recorded in diabetic rats when compared to the control rats. Marked recovery in insulin and glucose levels was recorded in diabetic animals pretreated and treated with vitamin D. HOMA-IR values were significantly higher in diabetic rats when compared to the corresponding controls, while pretreated and treated of diabetic rats with vitamin D returned HOMA-IR values to approximate normal value (Table 1). 
Table (1): Effect of vitamin $D$ on insulin resistance in diabetic rats (mean $\pm \mathrm{SE}$ )

\begin{tabular}{|c|c|c|c|c|}
\hline Groups & GI & GII & GIII & GIV \\
\hline Parameters & 99.81 & $216.36^{\mathrm{a}}$ & $114.4^{\mathrm{bc}}$ & $109.09^{\mathrm{bc}}$ \\
Fasting Glucose & \pm 0.11 & \pm 0.13 & \pm 0.20 & \pm 0.13 \\
$(\mathrm{mg} / \mathrm{dl})$ & 76.71 & $45.48^{\mathrm{a}}$ & $62.42^{\mathrm{bc}}$ & $68.32^{\mathrm{bc}}$ \\
\hline Fasting Insulin & \pm 0.14 & \pm 0.07 & \pm 0.33 & \pm 0.42 \\
\hline$(\mu \mathrm{U} / \mathrm{ml})$ & 18.90 & $24.25^{\mathrm{a}}$ & $17.63^{\mathrm{bc}}$ & $18.38^{\mathrm{bc}}$ \\
\hline HOMA-IR & \pm 0.19 & $\pm 0.40 \mathrm{~b}$ & $\pm 0.23 \mathrm{~b}$ & $\pm 0.30 \mathrm{~b}$ \\
\hline
\end{tabular}

$\mathrm{n}=10$ in each group

GI: control group.

GII: diabetic group.

GIII: diabetic group pre-treated vitamin D.

GIV: diabetic group treated vitamin D.

a: Significant as compared with normal control (I).

b: Significant as compared with the diabetic control (II).

c: insignificant GIII and GIV compared with each other.

Diabetic animals showed marked significant elevations in TG, TC, LDL and VLDL and high risk I and II accompanied with marked decline in HDL relative to the corresponding controls. In pretreated and treated diabetic rats with vitamin $\mathrm{D}$,

the sera lipids profile improved as shown by the significant reduction in the values of TG, TC, LDL and VLDL and low risk I and II associated with marked elevation of HDL (Table 2).

Table (2): Effect of vitamin D on lipid profiles in diabetic rats (mean \pm SE)

\begin{tabular}{|c|c|c|c|c|}
\hline $\begin{array}{l}\text { Groups } \\
\text { Parameters }\end{array}$ & GI & GII & GIII & GIV \\
\hline $\begin{array}{l}\text { Triglyceride } \\
(\mathrm{mg} / \mathrm{dl})\end{array}$ & $\begin{array}{r}80.32 \\
\pm 2.02 \\
\end{array}$ & $\begin{array}{l}182.51^{\mathrm{a}} \\
\pm 1.55\end{array}$ & $\begin{array}{c}107.75^{\text {bc }} \\
\pm 0.89\end{array}$ & $\begin{array}{c}95.80^{\mathrm{bc}} \\
\pm 1.11\end{array}$ \\
\hline $\begin{array}{c}\text { cholesterol } \\
(\mathrm{mg} / \mathrm{dl})\end{array}$ & $\begin{array}{r}93.24 \\
\pm 0.11 \\
\end{array}$ & $\begin{array}{l}144.22^{\mathrm{a}} \\
\pm 1.56\end{array}$ & $\begin{array}{l}99.16^{\text {bc }} \\
\pm 0.77\end{array}$ & $108.76^{\text {bc }} \pm 0.57$ \\
\hline $\begin{array}{l}\text { LDL-C } \\
(\mathrm{mg} / \mathrm{dl})\end{array}$ & $\begin{array}{l}23.81 \\
\pm 2.19\end{array}$ & $\begin{array}{l}77.40^{\mathrm{a}} \\
\pm 2.14\end{array}$ & $\begin{array}{l}24.73^{\mathrm{bc}} \\
\pm 1.29\end{array}$ & $\begin{array}{c}29.60^{\mathrm{bc}} \\
\pm 1.06\end{array}$ \\
\hline $\begin{array}{l}\text { HDL-C } \\
(\mathrm{mg} / \mathrm{dl})\end{array}$ & $\begin{array}{r}53.33 \\
\pm 0.72 \\
\end{array}$ & $\begin{array}{l}30.35^{\mathrm{a}} \\
\pm 1.66 \\
\end{array}$ & $\begin{array}{l}52.88^{\mathrm{bc}} \\
\pm 1.03 \\
\end{array}$ & $\begin{array}{c}59.97^{\mathrm{bc}} \\
\pm 1.01\end{array}$ \\
\hline $\begin{array}{l}\text { VLDL } \\
(\mathrm{mg} / \mathrm{dl})\end{array}$ & $\begin{array}{l}16.06 \\
\pm 0.70 \\
\end{array}$ & $\begin{array}{l}36.50^{\mathrm{a}} \\
\pm 0.22 \\
\end{array}$ & $\begin{array}{c}21.55^{\text {bc }} \\
\pm 0.18 \\
\end{array}$ & $\begin{array}{c}19.16^{\text {bc }} \\
\pm 0.15 \\
\end{array}$ \\
\hline Risk I & $1.74 \pm 0.01$ & $\begin{array}{l}4.75^{\mathrm{a}} \\
\pm 0.03\end{array}$ & $\begin{array}{l}1.87^{\mathrm{bc}} \\
\pm 0.02\end{array}$ & $1.81^{\mathrm{bc}} \pm 0.02$ \\
\hline Risk II & $0.44 \pm 0.00$ & $\begin{array}{l}2.55^{\mathrm{a}} \\
\pm 0.21\end{array}$ & $\begin{array}{l}0.46^{\mathrm{bc}} \\
\pm 0.01\end{array}$ & $0.49^{\mathrm{bc}} \pm 0.16$ \\
\hline
\end{tabular}

$\mathrm{n}=10$ in each group

GI: control group.

GII: diabetic group.

GIII: diabetic group pre-treated vitamin D.

GIV: diabetic group treated vitamin D.

a: Significant as compared with normal control (I).

b: Significant as compared with the diabetic control (II).

c: insignificant GIII and GIV compared with each other. 
A significant decrease in the platelet count and its mean volume was recorded in diabetic group when compared to the control group, marked decrease in both was recorded in pretreated and treated diabetic animals with vitamin D (Figures $1 \& 2)$.

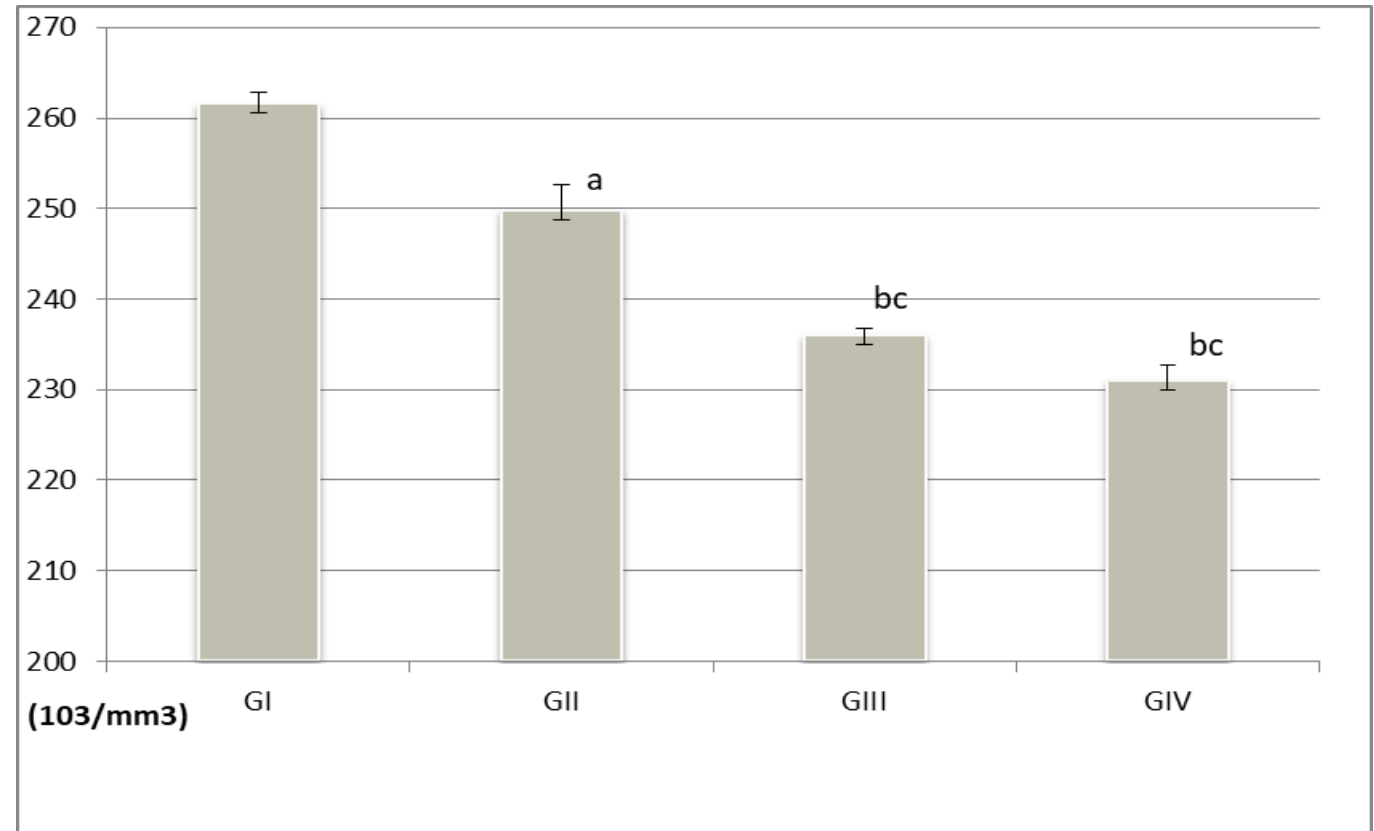

Figure (1): Effect of vitamin $D$ on platelet count in diabetic rats (mean \pm SE)

$\mathrm{n}=10$ in each group

GI: control group.

GII: diabetic group.

GIII: diabetic group pre-treated vitamin D.

GIV: diabetic group treated vitamin D.

a: Significant as compared with normal control (I).

b: Significant as compared with the diabetic control (II).

c: insignificant GIII and GIV compared with each other. 


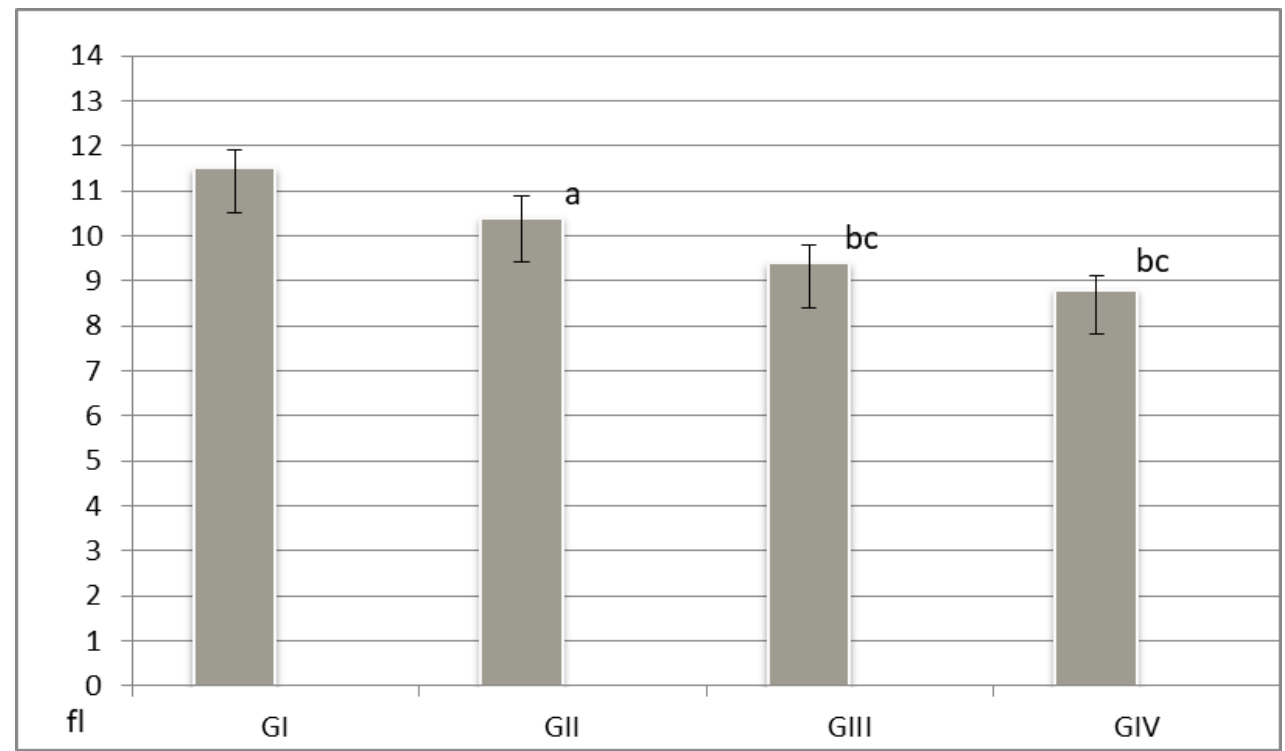

Figure (2): Effect of vitamin D on mean platelet volume in diabetic rats (mean $\pm \mathrm{SE}$ )

$\mathrm{n}=10$ in each group

GI: control group.

GII: diabetic group.

GIII: diabetic group pre-treated vitamin D.

GIV: diabetic group treated vitamin D.

a: Significant as compared with normal control (I).

b: Significant as compared with the diabetic control (II).

c: insignificant GIII and GIV compared with each other.

\section{DISCUSSION}

The current study showed significant decrease in fasting blood glucose level and HOMA-IR value and significant increase fasting serum insulin level in vitamin D pre-treated and treated groups compared to diabetic group but without significant differences between each other's. Experimental evidence highlights mechanisms by which vitamin D may influence glycaemic control; these include modulation of pancreatic Renin angiotensin system activity and regulation of calcium ion traffic across b-cells that directly affect insulin synthesis and secretion and subsequent insulin resistance (Soskić et al., 2014). Also, increased adiposity and body fat mass observed in most insulin-resistant subjects may partly account for the lower 25-OH D levels seen in this population, as lipidsoluble vitamin D may be sequestered in adipose tissue, thus decreasing 25-OH D bioavailability (Sarnali and Moyenuddin, 2010). Numerous evidences (Kavadar et al., 2015) showed that Vitamin D reduces the insulin resistance in the surrounding tissues and thus reduces the excessive insulin release in response to increased blood sugar due to insulin resistance. As a result, it increases the insulin sensitivity. Vitamin D does not only increase the production capacity of $\beta$-cells, it also accelerates the pro-insulin conversion (Ozkan, 2010).

In non-obese diabetic rats, the administration of high dose 1, 25hydroxy-vitamin D inhibits the onset of diabetes by immunomodulation. This effect is related to the effects of 
inflammatory cytokines (IL-6 and TNFalpha) on the beta-cell function. The application of this cytokine leads to hyperglycemia. Chronic administration of 1, 25-hydroxy vitamin $\mathrm{D}$ at pharmacological doses reduces the incidence of diabetes in non-obese diabetic rats (Soskić et al., 2014). Insulin secretion in rats with vitamin D deficiency showed a reduction of $48 \%$ when compared with rats receiving supportive treatment in the same group. After supportive care in rats with vitamin D deficiency, glucose tolerance and insulin secretion improve independently of nutritional factors, plasma calcium, and phosphorus concentrations (Alvarez and Ashraf, 2010).

The effect of vitamin D on healing of beta cell function can be directly or indirectly influenced. One of the most important proofs of direct effect is the expression of the DVR gene and 1-alpha hydroxylase gene in beta cells. Vitamin D has been reported to increase insulin secretion in response to glucose stimulation but not basal insulinemia. Disruption in response to insulin secretion has been shown in DVR knock-out mice. Human insulin promoter gene contains DVR, with the effect of active vitamin D human insulin gene gain transcriptional activity. In case of missing DVR insulin secretion which is induced by glucose is inhibited. Improvement of the insulin secretion due to the vitamin D supplementation is considered to be a direct effect of vitamin $\mathrm{D}$ on the improvement of beta-cell function (Kabadi et al., 2012). Fasting insulin, fasting glucose, and indirect insulin resistance index values were significantly lower in diabetic patients without insulin resistance compared to diabetic patients with insulin resistance. At the same time, fasting insulin and indirect insulin resistance index levels were significantly lower when the control group without insulin resistance and control group with insulin resistance were compared to each other (Cimbek et al., 2012). A study was conducted with 31 female patients who had BMI values more than 25-35. According to results, there was a negative correlation between low vitamin D levels, insulin, and HOMA index levels (Caglar et al., 2017).

Our study revealed significant low prevalence of hypercholesterolemia, hypertriglyceridemia; low LDL and high HDL levels in vitamin D pre-treated and treated groups compared to diabetic group. Few studies have been carried out on the relationship between serum levels of vitamin D and lipid profiles. Ahmad et al. (2014) indicate that there is a negative, but non-significant, relationship between serum levels of $25(\mathrm{OH}) \mathrm{D}$ and that of TG in diabetic patients. Also found a negative association between serum levels of 25(OH) $\mathrm{D}$ and $\mathrm{TG}$ in patients with hypertriglyceridemia. However, this relationship was not observed with regard to HDL cholesterol in healthy subjects. Rejnmark et al. (2010) performed a study among 82 healthy postmenopausal women who had been treated with either 40 $\mathrm{mg}$ /day Simvastatin or a placebo for 1 year, in which vitamin $\mathrm{D}$, TG, and LDL levels were measured at baseline and after 26 weeks of treatment. In this study, Simvastatin showed no effect on vitamin D status, but decreased the serum levels of TG and LDL. These results suggest that serum concentration of $\mathrm{TG}$ is inversely associated with serum level of $25(\mathrm{OH}) \mathrm{D}$. 
In contrast, Kelishadi et al. (2014) showed no relationship between serum levels of 25(OH) D and TG or HDL cholesterol in healthy subjects. Other study was a significant effect seen, with an $8 \%$ increase in serum LDL-C and a $16 \%$ decrease in serum $\mathrm{TG}$ in those given vitamin $\mathrm{D}$ as compared to the placebo group (Jorde and Grimnes, 2011). It was suggested that vitamin D has both direct and indirect effects on modifying the lipid profile and that the effect of vitamin $D$ on decreasing serum levels of TG may occur through regulatory action that increases the activity of lipoprotein lipase in adiposity (Wang et al., 2017).

When considering platelets and vitamin $\mathrm{D}$, we have to keep in mind that vitamin $\mathrm{D}$ receptor (VDR) has been recently found in platelets and thus megakaryocytopoiesis and platelet activation, which are calcium-dependent events, might be modulated by a mitochondrial non-genomic activity of VDR (Silvagno et al., 2010). In vitro and in vivo experiments indicated that the vitamin D-VDR system plays a pivotal role in antithrombogenicity (Ishii et al., 2014). Targher et al. (2012) also reported that activation of nuclear VDR elicits antithrombotic effects in vivo, and suggest that the VDR system could potentially play a physiological role in the maintenance of antithrombotic homeostasis. Hudzik et al. (2018) indicated that multimorbidity was associated with an increase in platelet volume indices. MPV values increased with the increasing number of comorbid conditions. Importantly, MPV values were elevated in a wide range of cardiovascular and non-cardiovascular diseases. Similar results were obtained by Kebapcilar et al.
(2013) who examined the relationship between mean platelet volume and lowgrade systemic coagulation with vitamin D deficiency in primary ovarian insufficiency. They reported that serum $25(\mathrm{OH}) \mathrm{D}$ was inversely correlated with MPV , activated partial thromboplastin time (APTT), and D-dimer . Thus, they indicated that vitamin D deficiency could be associated with hypercoagulability (Kebapcilar et al., 2013). These observed associations may be due to the close relationship between oxidative stress and platelet count. Vitamin D's role as an antioxidant is well known (Polidoro et al., 2013). Also, the Vitamin D has antithrombogenic, antiinflammatory, and anticoagulation activity, while MPV links thrombosis and inflammation (ShaikDasthagirisaheb et al., 2013).

\section{CONCLUSION}

Vitamin $D$ can be effective in inhibition and decreasing of insulin resistance, dyslipidemia and coagulation activity, consequently the improvement of diabetes and its complications.

\section{REFERENCES}

1. Ahmad S., Ehsaneh T., Mahmoud D., Ali M.M. and Mostafa Q (2014): Association between serum level of vitamin $\mathrm{D}$ and lipid profiles in type 2 diabetic patients in Iran. J Diabetes Metab Disord., 13:14-28.

2. Alvarez JA and Ashraf A (2010): Role of vitamin $\mathrm{D}$ in insulin secretion and insulin sensitivity for glucose homeostasis. Int $\mathbf{J}$ Endocrinol., 10: 351-385.

3. Burstein RF and Scholnick VS (1972): Biochemistry and methodology of lipids. J Lipid Res., 25: 375-382.

4. Caglar FNT, Isiksacan N, Kocamaz N and Akturk F (2017): The Association among vitamin $\mathrm{D}$, insulin resistance, and obesity in Turkish women. Shiraz E-Med J, 18: 925-944. 
5. Cimbek A, Gürsoy G, Kirnap NG, Acar Y, Erol B, Özaşik I and Güngör F (2012): Relation of serum 25 hydroxy vitamin D3 levels with insulin resistance in type 2 diabetic patients and normal subjects. Med Sci., 1: 305-314.

6. Fossati $P$ and Principe $L$ (1982): Serum triglycerides determined calorimetrically with an enzyme that produces hydrogen peroxide. ClinChem., 28: 2077-2080.

7. Friedewald WT, Levey RI and Fredrickson DS (1972): Estimation of the concentration of low density lipoprotein cholesterol in plasma without use of the preparative ultracentrifuge. Clin. Chem., 18:499-502.

8. Henry RJ, Cannon DC and Winkelman JW (1997): Clinical Chemistry Principles and Tetchiness, pbl. New York: Harper and Row: p. 1440 .

9. Hudzik B, Korzonek-Szlacheta I, Szkodzinski J, Liszka R, Lekston A, Zubelewicz-Szkodzinska $B$ and Gasior $M$. (2018): Association between multimorbidity and mean platelet volume in diabetic patients with acute myocardial infarction. Acta Diabetol., 55(2):175-183.

10. Ishii T, Miyazawa $M$ and Takanashi $Y$ (2014): Genetically induced oxidative stress in mice causes thrombocytosis, splenomegaly and placental angiodysplasia that lead to recurrent abortion. Redox Biol., 2:679-685.

11. Jorde $\mathbf{R}$ and Grimnes $\mathbf{G}$ (2011): Vitamin D and metabolic health with special reference to the effect of vitamin D on serum lipids. Prog Lipid Res., 50(4):303-312.

12. Kabadi SM, Lee BK and Liu L (2012): Joint effects of obesity and vitamin D insufficiency on insulin resistance and type 2 diabetes. Diabet Care, 35: 2048-2054.

13. Kavadar G, Demircioğlu DT, Özgönenel L and Emre TY. (2015): The relationship between vitamin D status, physical activity and insulin resistance in overweight and obese subjects. Bosn J Basic Med Sci., 15: 62-66.

14. Kebapcilar AG, Kulaksizoglu M, Ipekci SH, Korkmaz H, Kebapcilar $L$ and Akyurek F (2013): Relationship between mean platelet volume and low-grade systemic coagulation with vitamin D deficiency in primary ovarian insufficiency. Arch Gynecol Obstet., 288(1):207-212.

15. Kelishadi, R.; Salek, S.; Salek, M.; Hashemipour, $M$ and Movahedian, $M$. (2014): Effects of vitamin d supplementation on insulin resistance and cardiometabolic risk factors in children with metabolic syndrome: A trolpe-masked controlled trial. J. Pediatr., 90: 28-34.

16. Maren L.N., Alexander G., Laura H., Beatrice R., Karin S and Dagmar C. (2017): Vitamin D treatment attenuates cardiac FGF23/FGFR4 signaling and hypertrophy in uremic rats: Nephrol Dial Transplant., 1-12.

17. Ozkan B. (2010): Nutritional rickets. J Clin Res Pediatr Endocrinol., 4: 137-143.

18. Pajor, I.S. and Sliwinska, A. (2019): Analysis of association between vitamin D deficiency and insulin resistance. Nutrients, 1 : 794-803.

19. Polidoro L, Properzi G and Marampon F. (2013): Vitamin D protects human endothelial cells from $\mathrm{H}$ (2) $\mathrm{O}(2)$ oxidant injury through the Mek/Erk-Sirt1 axis activation. J Cardiovasc Transl Res., 6(2):221-231.

20. Rejnmark L, Vestergaard P, Heickendorff L and Mosekilde L. (2010): Simvastatin does not affect vitamin D status, but low vitamin D levels are associated with dyslipidemia: results from a randomised controlled trial. Inte $\mathrm{J}$ Endocr., 6: 157-174

21. Sarnali TT, and Moyenuddin PK. (2010): Obesity and disease association: A Review. AKMMC J., 1: 21-24.

22. Shaik-Dasthagirisaheb YB, Varvara $G$ and Murmura G. (2013): Role of vitamins D, E and $\mathrm{C}$ in immunity and inflammation. $\mathrm{J}$ Biol Regul Homeost Agents, 27(2):291-295.

23. Silvagno F, De Vivo E, Attanasio A, Gallo V, Mazzucco G and Pescarmona G (2010): Mitochondrial localization of vitamin D receptor in human platelets and differentiated megakaryocytes. PLoSOne, 5(1):70-86.

24. Soskić S, Stokić E, and Isenović ER. (2014): The relationship between vitamin $\mathrm{D}$ and obesity. Curr Med Res Opinion, 30-39. 
25. Szkudelski T. (2001): The mechanism of Alloxan and alloxan Action in $\beta$ cells of the rats pancreas. Physiol Res., 50: 536- 546.

26. Targher G, Pichiri I, and Lippi G (2012): Vitamin D, thrombosis, and hemostasis: more than skin deep. Semin Thromb Hemost., 38(1):114-124.
27. Trinder P. (1969): Determination of glucose in blood using glucose oxidase with an alternative oxygen acceptor. Ann. Clin. Biochem., 6: 24-33.

28. Wang, H.; Chen, W.; Li, D.; Yin, X.; Zhang, X.; Olsen, N. and Zheng, S.G. (2017): Vitamin D and Chronic Diseases. Aging Dis., 8: 346-353. 
EFFECT OF PRE-TREATED AND TREATED VITAMIN D ON INSULIN... 819

تأثنير فيتامين د المُعالج مسبقًا و المُعالج على مقاومة الانسولين

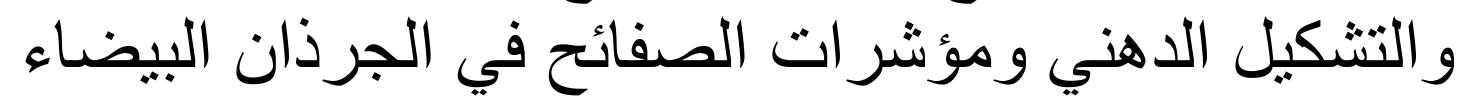

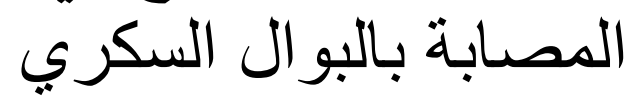

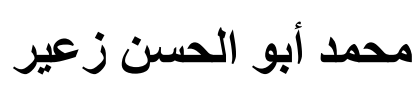

قسم الفسيولوجيا الطبية، كلية الطب، جامعة الأزهر، القاهرة

E-mail: drmohammads74@azhar.edu.eg

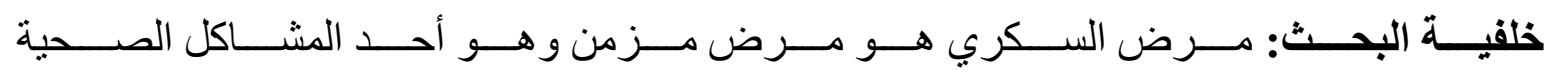

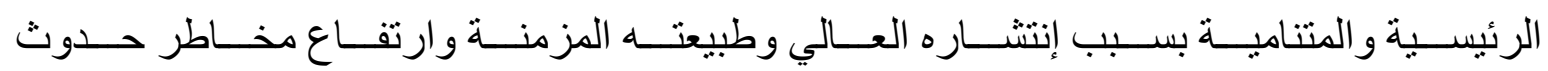

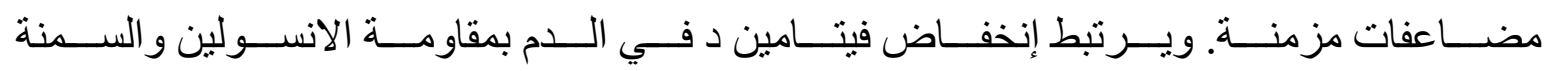
و عدم تحمل الجلوكوز ومرض ولن السكري.

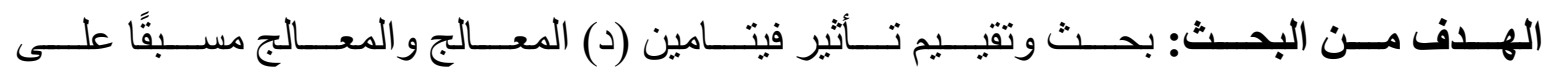

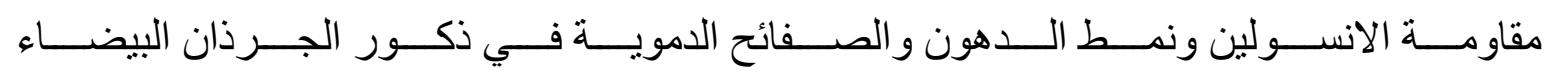
المصابة بداء السكري.

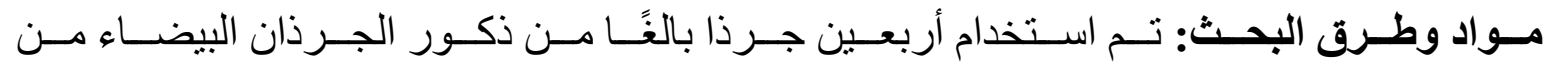

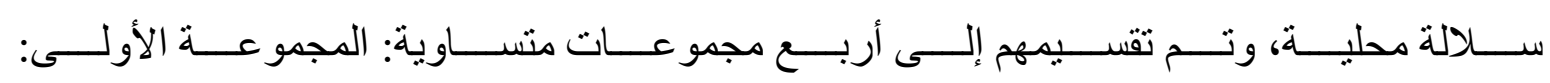

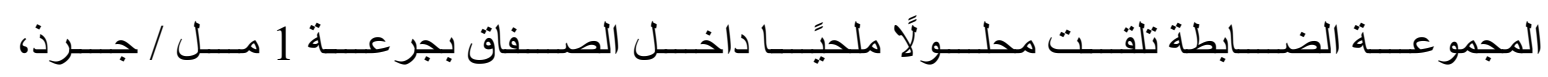

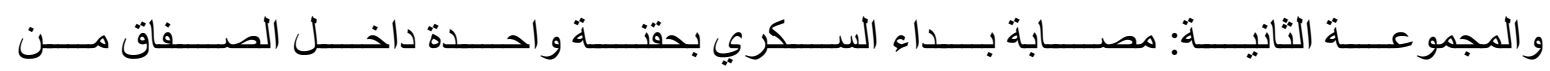

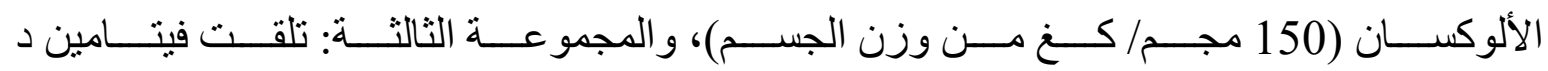

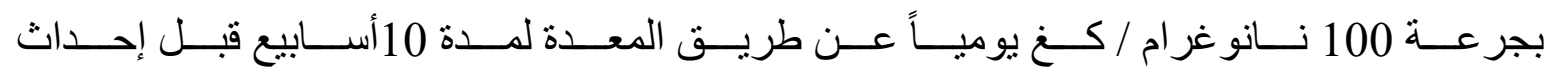

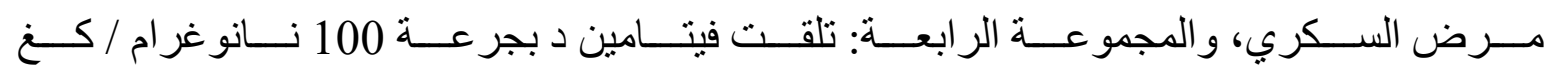

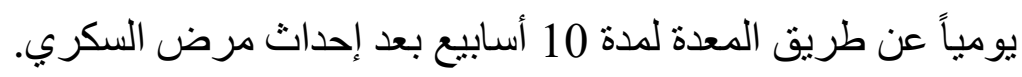

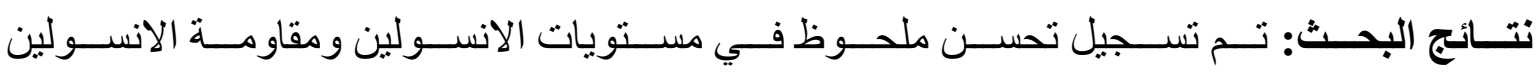

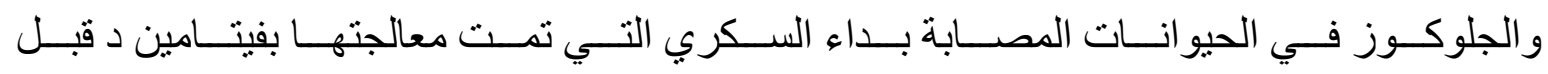

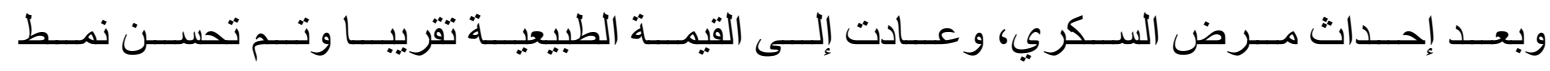

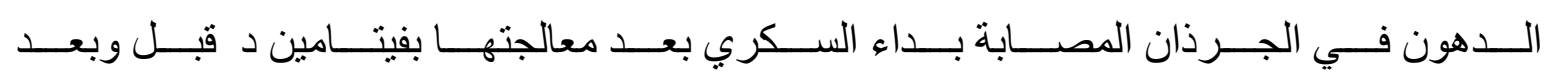

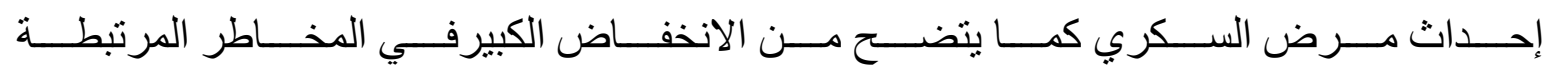




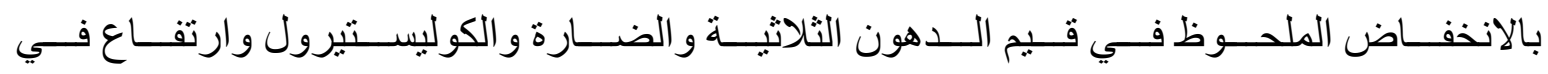
قيم الدهون النافعة.

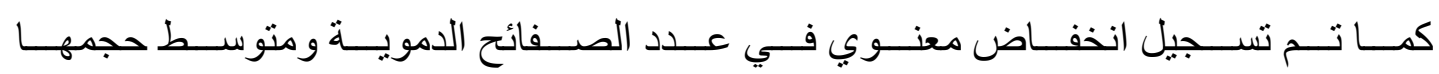
في الحيو انات المصابة بداء السكري المعالجة مسبقا و المعالجة بفيتامين د.

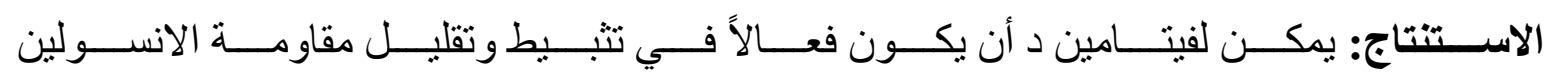
و عسر دهون الدم ونشاط التخثر ، وبالتالي تحسين مرض السكري و مضاعفاته.

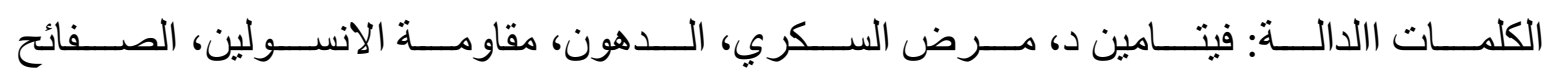
الدموية. 